\title{
A Comparison of Three Methods of Estimating Digestibility for Determining Intake of Grazing Cattle
}

\section{WILLIAM P. HANDL AND LARRY R. RITTENHOUSE}

Highlight: In vitro plus pepsin digest (IVP), lignin ratio $(L R)$, and in vitro plus neutral detergent digest (IVND) were of about equal value in estimating digestibility of spring forage grazed by steers, provided the limitations of each were considered. However, when these methods of estimating digestibility were used to estimate intake, only the IVP and LR methods gave realistic results. The IVND results were lower than the expected physical capacity of the animals, and indicated further study of this method is needed.

Digestibility of grazed herbage cannot be determined directly because intake cannot be measured. Many techniques have been developed to estimate dry matter digestibility of grazed herbage. Selection of an indirect technique to estimate in vivo digestibility is complicated by many variables (Streeter, 1969). Currently, techniques using indicator ratios or in vitro digestion are most widely accepted.

For the scientist who is conducting grazing trials of any extent, the main criterion for selecting a technique is one which results in a minimum amount of time and expendable effort in both field collection and laboratory analysis, yet gives reliable results. Our study compared two in vitro digestion techniques and the lignin ratio (LR) as methods of estimating in vivo digestibility for determination of total voluntary intake of grazing steers. Twelve trials were conducted over a period of 2 years.

Authors are graduate assistant and assistant professor, Rangeland Resources Program, Squaw Butte Experiment Station, Burns, Oregon 97720. Handl at present is with the Forestry Sciences Laboratory, Bozeman, Montana 59715.

The study is a contribution from the Squaw Butte Experiment Station, Burns, Ore. This Station is jointly operated by Oregon Agricultural Experiment Station, Oregon State University, and Agricultural Research Service, U.S. Department of Agriculture. Technical Paper number 3907. Oregon Agricultural Experiment Station.

Manuscript received October 26, 1974.

\section{Methods}

The study was conducted during the springs of 1970 and 1971 on a crested wheatgrass (Agropyron desertorum (Fisch.) Schult.) pasture located at the Squaw Butte Range Station in southeastern Oregon. Herbage samples were obtained from (1) a representative sample of hand-clipped material used to estimate pasture production during 1970 and 1971; and (2) dietary samples collected from eight esophageally fistulated steers in 1971. Total fecal collections were obtained from a separate group of eight yearling steers averaging $270 \mathrm{~kg}$. All samples were dried at $50^{\circ} \mathrm{C}$ in a forced air oven, ground through a Wiley mill to pass a 20 -mesh screen, and daily aliquots composited for each animal.

Lignin was analyzed using the method of Van Soest (1963) and cell wall constituents (CWC) by the method of Van Soest and Wine (1967). In vitro digestibility was determined by the methods of Tilley and Terry (1963), using a 48-hour pepsin digest (IVP), and Van Soest et al. (1966), using a CWC digest (IVND).

Estimates of dry matter intake (DMI) were calculated from fecal production values and estimates of dry matter digestibility (DMD) using the following formulae:

$$
\begin{aligned}
& \text { DMI by LR }=(\text { Fecal production, } \mathrm{kg}) \frac{(\text { Lignin, feces) }}{\text { (Lignin, feed })} \\
& \text { DMI by IVD }=\frac{\mathrm{kg} \text { fecal production }}{1-\text { dry matter disappearance coef. }} \\
& \text { DMI by IVND }=\frac{\mathrm{kg} \text { fecal production of CWC }}{1-\text { dry matter disappearance coef. }}
\end{aligned}
$$

The method of Van Soest et al. (1966) is an algebraic identity of the microdigestion technique proposed by Van Dyne and Meyer (1964), except the Van Soest method utilizes digestible CWC rather than digestible cellulose. Since IVND approximates true $\mathrm{DMD}$, the need for a conventional digestion 
Table 1. Digestibility $(\%)$ of crested wheatgrass using three methods in vitro plus pepsin digestion (IVP), lignin ratio (LR), and in vitro plus neutral detergent extraction (IVND).

\begin{tabular}{lclll}
\hline \multirow{2}{*}{$\begin{array}{c}\text { Dates } \\
\text { included }\end{array}$} & $\begin{array}{c}\text { Number } \\
\text { of trials }\end{array}$ & IVP & LR & IVND \\
\cline { 3 - 5 } $4 / 28-5 / 28 / 70$ & 5 & $65 \mathrm{x}$ & $67 \mathrm{x}$ & $75 \mathrm{z}$ \\
$6 / 6-6 / 18 / 70$ & 3 & $58 \mathrm{x}$ & $61 \mathrm{x}$ & $68 \mathrm{z}$ \\
$4 / 14-6 / 8 / 71$ & 4 & $61 \times(60) \mathrm{x}$ & $62 \mathrm{x}(56) \mathrm{x}$ & $73 \mathrm{z}(76) \mathrm{z}$ \\
Mean & & $61 \mathrm{x}$ & $63 \mathrm{x}$ & $72 \mathrm{z}$ \\
\hline
\end{tabular}

a Values in parenthesis were determined from diet samples.

$b$ Means within rows followed by the same let ter are not different at the 0.05 probability level; clipped and diet samples analyzed separately.

trial is eliminated (see Van Soest et al., 1966).

Trial means were compared using Duncan's Multiple Range test following an analysis of variance. Homogenity of regression slopes was tested with an analysis covariance.

\section{Results and Discussion}

Digestibility estimated from the in vitro plus neutral detergent extraction method (IVND) was higher than DMD

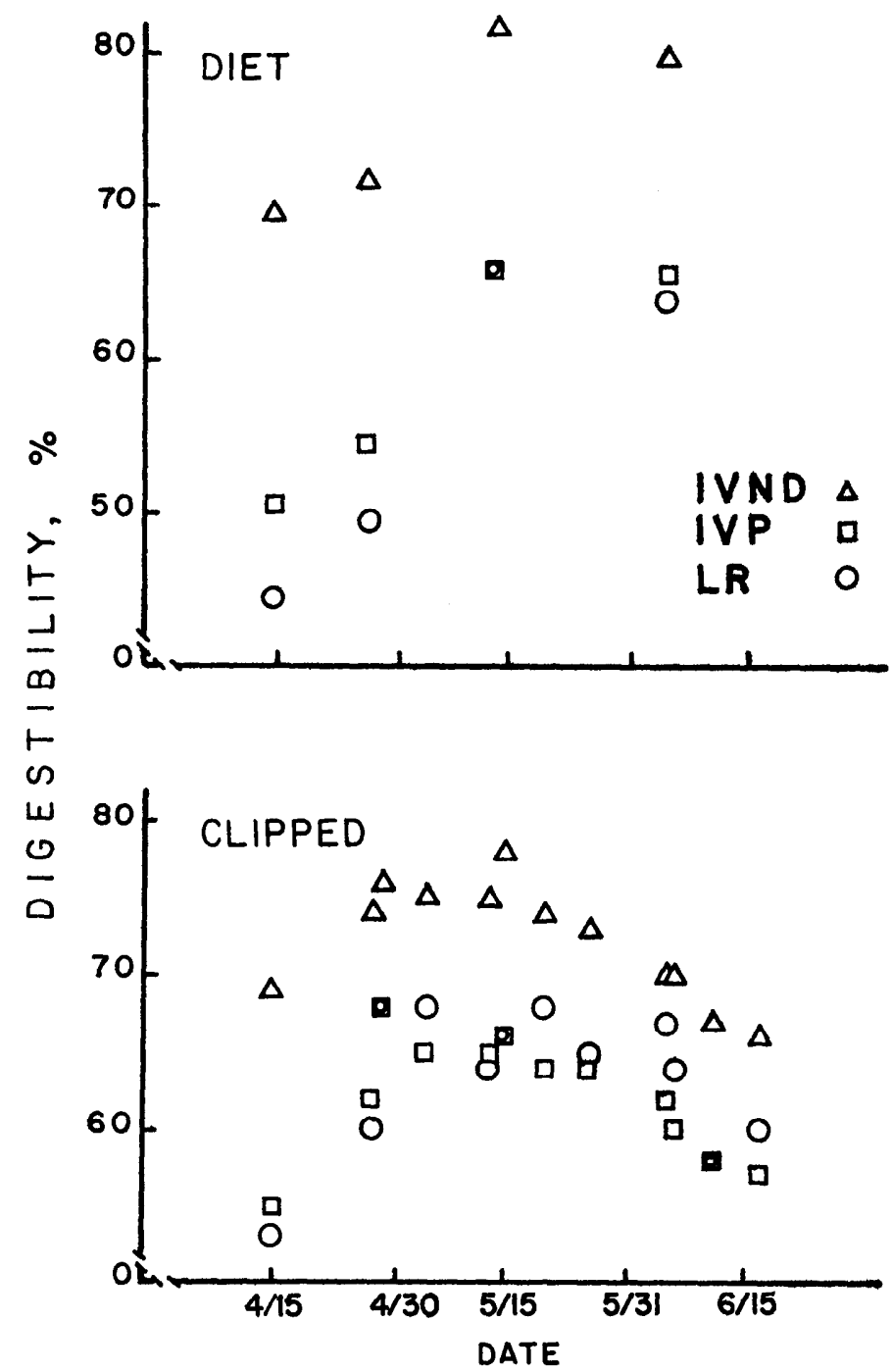

Fig. 1. Digestibility of clipped and diet samples of crested wheatgrass herbage on various dates from three methods, i.e., lignin ratio (LR), in vitro plus pepsin digest (IVP) and in vitro plus neutral detergent digest (IVND). determined from either the in vitro plus pepsin digestion (IVP) or lignin ratio (LR) methods, i.e., 72 vs 61 and $63 \%$, respectively (Table 1). This was consistent in all 12 trials. As discussed by Van Soest et al. (1966) the difference between the IVP and IVND methods can be attributed to removal of bacterial residue by neutral detergent extraction, whereas, bacterial residue remains following pepsin digestion. The LR method is not influenced by endogenous and/or bacterial residues.

In theory an in vitro technique should give the best estimate of in vivo DMD because all factors and inhibitors known and unknown influence the results (Van Soest, 1970). On the herbage used in this study, there was little advantage of one in vitro method over the other for showing changes in DMD with advance in season and maturity of herbage (Fig. 1). The LR method gave results comparable to the two in vitro techniques.

Through analysis of covariance, the homogeneity of regression slopes between the LR and IVP methods were compared with the IVND method (Fig. 2). No significant difference $(P>0.10)$ was found between either clipped or diet samples. The amount of variation among diet samples was small compared to clipped samples. Within clipped samples the IVP method accounted for more variation than the $L R\left(R^{2}=\right.$ 0.80 and 0.40 , respectively). This would be expected since both IVP and IVND were in vitro techniques. Experience and the literature (Streeter, 1969) have shown reason for caution in the use of lignin as an internal indicator when lignin concentrations in the herbage are less than $5 \%$. Lignin values in this study ranged from 2.7 to $5.2 \%$. Van Soest (1970) has also adequately cautioned against incomplete recovery because of artifact lignin and the Maillard reaction.

Dry matter intake of grazing steers (Table 2) was estimated from the fecal production-indigestibility ratio (Equations 1, 2 , and 3), utilizing estimates of DMD determined from the three methods, i.e., LR, IVP, or IVND. Estimates of DMI using

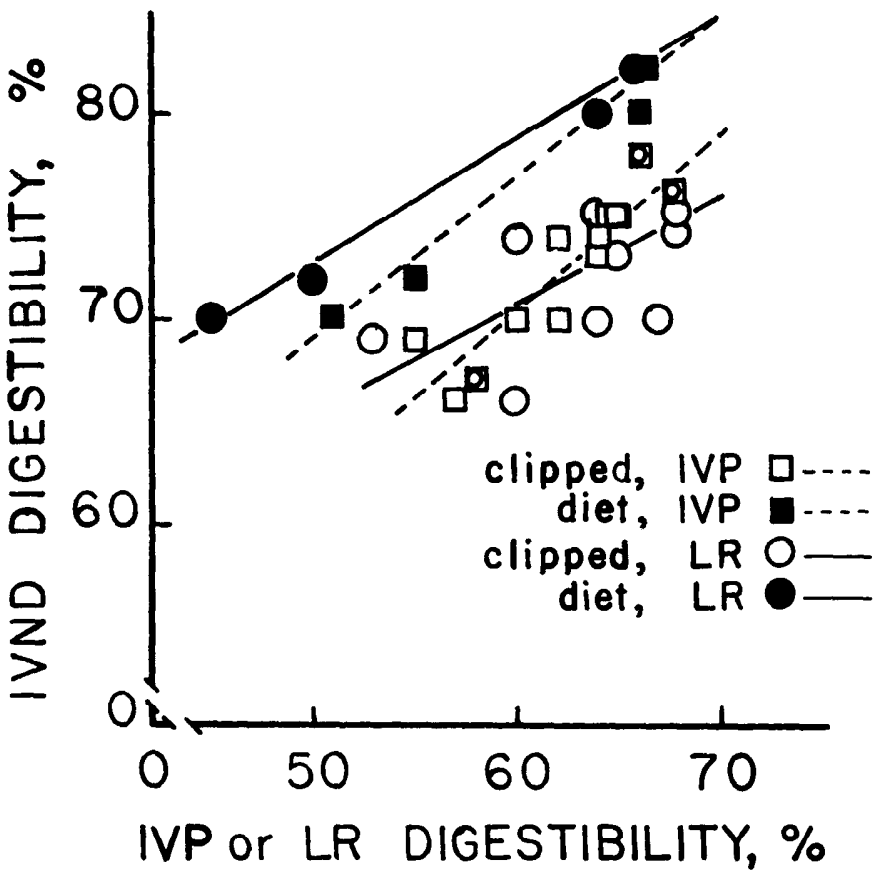

Fig. 2. A comparison of in vitro plus pepsin digest (IVP) and lignin ratio (LR) digestibilities with in vitro plus neutral detergent digest (IVND) on clipped and diet samples. 
Table 2. Dry matter intake $(\mathrm{kg})$ of steers grazing crested wheatgrass determined from three methods of estimating digestibility. ${ }^{a}$

\begin{tabular}{lclll}
\hline \multirow{2}{*}{$\begin{array}{c}\text { Dates } \\
\text { included }\end{array}$} & $\begin{array}{c}\text { Number } \\
\text { of trials }\end{array}$ & \multicolumn{3}{c}{ Dry matter intake IVP $^{\mathrm{b}, \mathrm{c}}$} \\
\hline $4 / 28-5 / 28 / 70$ & 5 & $7.2 \mathrm{x}$ & $\mathrm{LR}$ & IVND \\
$6 / 6-6 / 18 / 70$ & 3 & $6.7 \mathrm{x}$ & $7.1 \mathrm{x}$ & $5.3 \mathrm{z}$ \\
$4 / 14-6 / 8 / 71$ & 4 & $6.5 \times(6.4) \times$ & $6.6 \mathrm{x}(5.9) \times$ & $5.3 \mathrm{x}$ \\
Mean & & $6.8 \mathrm{x}$ & $7.1 \mathrm{x}$ & $5.2 \mathrm{z}$ \\
\hline
\end{tabular}

${ }^{\text {a }}$ IVP $=$ in vitro plus pepsin digest $;$ LR $=$ lignin ratio; IVND $=$ in vitro plus neutral det ergent digest.

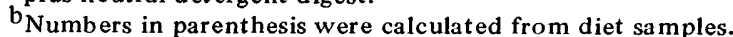

${ }^{c}$ Means within rows followed by the same letter are not different at the 0.05 probability level; clipped and diet samples analyzed separately.

Equation 1 (digestibility by LR) were not significantly $(P>$ 0.05 ) different from DMI estimated using Equation 2 (IVP digest). Estimates of DMI using Equation 3 (IVND) were lower than those estimated from either the LR or IVP methods (5.2 vs 6.8 and $7.1 \mathrm{~kg}$, respectively). Estimates of DMI using equations 1 or 2 were reasonable based on the expected intake of these animals, i.e., about $110 \mathrm{~g}$ per $\mathrm{BW}_{\mathrm{kg}}^{0.75}$. The estimates of DMI obtained using Equation 3 were lower than the expected physical capacity of the steers.

Any differences in DMI between Equations 1 and 2 would be a direct result of differences in estimated DMD between the LR and IVP methods. Comparatively, the lower DMI values obtained by using Equation 3 could have been either a reflection of the method utilized to estimate true digestibility (IVND) or the method used to determine percentage cell wall constituents in fecal samples. Since difficulties in filtering the highly proteinaceous fecal samples were encountered, the latter seems probable. Furthermore, using the summative equation of Van Soest (1967), assuming 12.9 as an estimate of metabolic excretion to estimate DMD, resulted in estimates of intake similar to IVP and LR methods. Filtering of herbage samples was not a problem.

\section{Summary and Conclusions}

This study compared the lignin ratio (LR), in vitro (pepsin digest) (IVP), and in vitro (neutral detergent digest) (IVND) methods of estimating in vivo digestibility for determining intake of grazing steers, during 12 trials.

For purposes of estimating digestibility, each of the methods gave reasonable results. Because the herbage dry matter was highly digestible (average 62\% apparent and $72 \%$ true), variation among methods was small and each responded similarly within dates.

Dry matter intake determined using the IVP and LR methods of estimating DMD were more realistic than DMI determined using true digestibility estimated from the IVND method. Further study of the latter technique is needed. Apparently, some of the inaccuracy results from laboratory preparation of the CWC fraction.

Considering the previous discussion on lignin, the IVP and LR methods of estimating digestibility are suitable for determining intake of herbage grazed in the spring. However, when other factors such as time required and ease of use are considered, the IVP method may be more realistic when large numbers of samples are involved.

\section{Literature Cited}

Streeter, C. L. 1969. A review of techniques used to estimate the in vivo digestibility of grazed forage. J. Anim. Sci. 29:757-768.

Tilley, J. M. A., and R. A. Terry. 1963. A two-stage technique for the in vitro digestion of forage crops. J. Brit. Grassl. Soc. 18:104-111.

Van Dyne, G. M., and J. H. Meyer. 1964. A method for measurement of forage intake of grazing livestock using microdigestion techniques. J. Range Manage. 17:204-208.

Van Soest, P. J. 1963. The use of detergents in the analysis of fibrous feeds. II. A rapid method for the determination of fiber and lignin. J. Ass. Offic. Agr. Chem. 46:829-835.

Van Soest, P. J. 1967. Development of a comprehensive system of feed analysis and its application to forages. J. Anim. Sci. 26:119-128.

Van Soest, P. J. 1970. The chemical basis for the nutritional evaluation of forages. In: Proceedings of the National Conference on Forage Quality Evaluation and Utilization, Lincoln, Nebraska, 1969. Lincoln, Nebraska Center for Continuing Education. p. U-1-U-19.

Van Soest, P. J., and R. H. Wine. 1967. Use of detergents in the analysis of fibrous feeds. IV. Determination of plant cell-wall constituents. J. Ass. Offic. Agr. Chem. 50:50-55.

Van Soest, P. J., R. H. Wine, and L. A. Moore. 1966. Estimation of the true digestibility of forage by the in vitro digestion of cell walls. Proc. 10th Int. Grassl. Cong. 10:438-441.

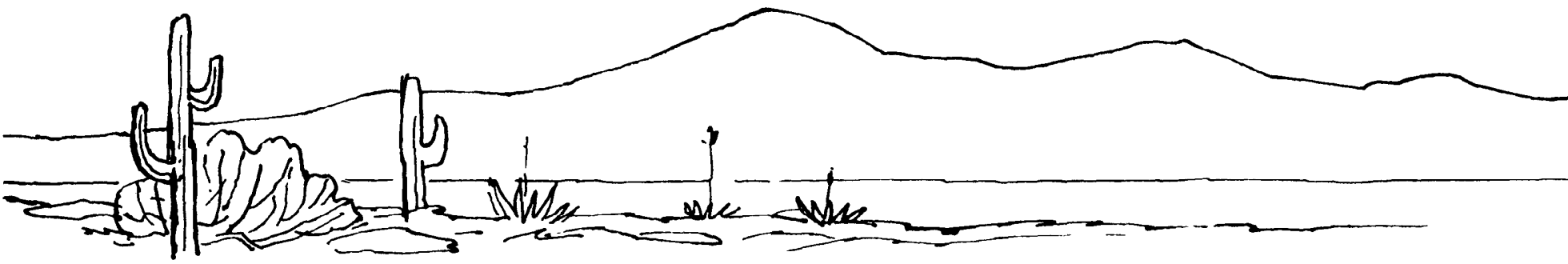

